\title{
Proteomics reveals a core molecular response of Pseudomonas putida F1 to acute chromate challenge
}

\author{
Dorothea K Thompson*+1, Karuna Chourey², Gene S Wickham¹1, Stephanie B Thieman1', Nathan C VerBerkmoes², \\ Bing Zhang ${ }^{3}$, Andrea T McCarthy'1, Matt A Rudisill1, Manesh Shah ${ }^{4}$ and Robert L Hettich*2
}

\begin{abstract}
Background: Pseudomonas putida is a model organism for bioremediation because of its remarkable metabolic versatility, extensive biodegradative functions, and ubiquity in contaminated soil environments. To further the understanding of molecular pathways responding to the heavy metal chromium( $(\mathrm{VI})[\mathrm{Cr}(\mathrm{VI})]$, the proteome of aerobically grown, $\mathrm{Cr}(\mathrm{VI})$-stressed $P$. putida strain F1 was characterized within the context of two disparate nutritional environments: rich (LB) media and minimal (M9L) media containing lactate as the sole carbon source.

Results: Growth studies demonstrated that F1 sensitivity to $\mathrm{Cr}(\mathrm{VI})$ was impacted substantially by nutrient conditions, with a carbon-source-dependent hierarchy (lactate $>$ glucose $>>$ acetate) observed in minimal media. Twodimensional HPLC-MS/MS was employed to identify differential proteome profiles generated in response to $1 \mathrm{mM}$ chromate under LB and M9L growth conditions. The immediate response to $\mathrm{Cr}(\mathrm{VI})$ in LB-grown cells was up-regulation of proteins involved in inorganic ion transport, secondary metabolite biosynthesis and catabolism, and amino acid metabolism. By contrast, the chromate-responsive proteome derived under defined minimal growth conditions was characterized predominantly by up-regulated proteins related to cell envelope biogenesis, inorganic ion transport, and motility. TonB-dependent siderophore receptors involved in ferric iron acquisition and amino acid adenylation domains characterized up-regulated systems under $\mathrm{LB}-\mathrm{Cr}(\mathrm{VI})$ conditions, while DNA repair proteins and systems scavenging sulfur from alternative sources (e.g., aliphatic sulfonates) tended to predominate the up-regulated proteome profile obtained under M9L-Cr(VI) conditions.

Conclusions: Comparative analysis indicated that the core molecular response to chromate, irrespective of the nutritional conditions tested, comprised seven up-regulated proteins belonging to six different functional categories including transcription, inorganic ion transport/metabolism, and amino acid transport/metabolism. These proteins might potentially serve as indicators of chromate stress in natural microbial communities.
\end{abstract}

\section{Background}

Pseudomonas putida is a ubiquitous gram-negative, saprophytic bacterium belonging to the gamma class of the Proteobacteria. Endowed with a remarkable environmental adaptability, $P$. putida strain F1 [1], for example, has been investigated most extensively as a model organism

\footnotetext{
*Correspondence: dthomps4@utk.edu, hettichrl@ornl.gov

1 Department of Biological Sciences, Purdue University, 915 W. State Street, West Lafayette, IN 47907, USA

2 Chemical Sciences Division, Oak Ridge National Laboratory, Oak Ridge, TN 37831, USA

+ Contributed equally

Full list of author information is available at the end of the article
}

for the microbial degradation of such xenobiotic aromatic compounds as toluene, benzene, and ethylbenzene [2]. Considerably less scientific focus has been devoted to elucidating the molecular basis of heavy metal resistance functions exhibited by $P$. putida strains. Genomic analysis of $P$. putida strain KT2440 revealed an unexpectedly large repertoire of genes predicted to be involved in metal homeostasis, tolerance, and resistance, inferring that the organism is habituated to heavy metal exposure in its environment [3]. P. putida strains, for instance, have been isolated from the effluent of previously operated mercury-reducing bioreactors [4], and Pseudomonas spp.

( 2010 Thompson et al; licensee BioMed Central Ltd. This is an Open Access article distributed under the terms of the Creative ComBFoMed Central mons Attribution License (http://creativecommons.org/licenses/by/2.0), which permits unrestricted use, distribution, and reproduction in any medium, provided the original work is properly cited. 
were reported to be dominant members of heavy metalcontaminated U.S. Department of Energy (DOE) sites, including a subsurface paleosol microbial community [5] and uranium-contaminated groundwater environment [6].

Hexavalent chromium [ $\mathrm{Cr}(\mathrm{VI})]$, in the form of chromate $\left(\mathrm{CrO}_{4}{ }^{2-}\right)$ or dichromate $\left(\mathrm{Cr}_{2} \mathrm{O}_{7}{ }^{2-}\right)$, is a widely distributed environmental contaminant due to its prevalent use in industrial and military defense applications $[7,8]$. Microbially mediated reduction of soluble, toxic $\mathrm{Cr}(\mathrm{VI})$ to sparingly soluble, less toxic $\mathrm{Cr}(\mathrm{III})$ is a potentially promising strategy for the in situ remediation of $\mathrm{Cr}(\mathrm{VI})$ contaminated subsurface environments. Priester et al. [9] demonstrated that unsaturated biofilms of $P$. putida strain $\mathrm{mt}-2$ on membranes overlaying iron-deficient solid media either containing dichromate or solid dichromatecoated hematite were able to completely reduce $\mathrm{Cr}(\mathrm{VI})$ under both conditions. Additionally, efficient and rapid reduction of $\mathrm{Cr}(\mathrm{VI})$ to $\mathrm{Cr}(\mathrm{III})$ has been measured for a soluble flavoprotein (ChrR) purified and kinetically characterized from P. putida MK1 [10,11] and for soluble crude fractions prepared from P. putida PRS2000 [12], suggesting that $P$. putida, if present in the indigenous microbial community, is likely an important contributor to the bioreduction of chromate in polluted soil environments. Surprisingly, there is a paucity of information on the physiological and global molecular response of $P$. putida to exogenous metals such as chromate, despite the fact that this soil bacterium has been used as a model organism for vadose zone bioremediation in various studies $[9,13,14]$. The availability of the genome sequences for P. putida strains F1 [DOE Joint Genome Institute (JGI); http://genome.jgi-psf.org/finished_microbes/psepu/ psepu.home.html] and KT2440 [15] provides an opportunity to access its metabolic versatility and explore the molecular basis for its enhanced ability to adapt to the various environmental conditions present in pristine and metal-contaminated soils.

Here we define the growth sensitivity of P.putida F1 to chromate when cultivated in complex (Luria Bertani) medium compared to defined minimal medium containing three different single carbon and energy sources (glucose, lactate, or acetate). Using a liquid-chromatography mass spectrometry-based "bottom-up" proteomic approach, we analyzed the global proteome profiles of F1 in an attempt to provide insight into the molecular systems underlying the cellular stress response to an acute exposure of chromate. In general, the chromate-perturbed F1 proteome was markedly different depending on whether challenged cells were cultivated in LB broth or minimal medium with lactate as the single carbon substrate. A core protein response to chromate, irrespective of the nutritional environment tested, is described and may provide potential in situ biomarkers for environmen- tal biomonitoring of heavy metal stress in natural microbial communities.

\section{Results}

Impact of nutritional environment on P. putida growth and $\mathrm{Cr}(\mathrm{VI})$ reduction

To assess the physiological impact of nutrient conditions on P. putida F1 sensitivity to $\mathrm{Cr}(\mathrm{VI})$, we determined the minimal inhibitory concentrations (MICs) of chromate for F1 in LB and M9 minimal media supplemented with $50 \mathrm{mM}$ glucose (M9G), $50 \mathrm{mM}$ sodium lactate (M9L), or $67 \mathrm{mM}$ sodium acetate (M9A) as the sole carbon source in the presence of $\mathrm{K}_{2} \mathrm{CrO}_{4}$ at concentrations ranging from 0.04 to $14 \mathrm{mM}$. F1 cells exhibited markedly different tolerance responses to chromate depending on the nutritional environment. The MIC of $\mathrm{Cr}(\mathrm{VI})$ for LBpropagated F1 cells was $>4 \mathrm{mM}$ (Figure 1A), an approximately 40 -fold greater concentration than that observed for F1 cells grown in M9 media irrespective of carbon source (MIC $>0.1 \mathrm{mM}$ ) (Figure 1B). Among the different minimal media, the nature of the carbon source influenced the growth ability of F1 in the presence of chromate. Higher ODs were measured for M9G in the absence of and at the lowest $\mathrm{Cr}(\mathrm{VI})$ concentration $(0.04$ $\mathrm{mM})$ tested than for M9L and M9A. As Cr(VI) concentrations were increased, however, M9L supported growth to higher cell densities than either M9G or M9A, and at the highest levels of chromate tested, $0.08 \mathrm{mM}$ and 0.1 $\mathrm{mM}$, cell densities in M9L surpassed those in M9G by 3and 9-fold, respectively (Figure 1B). Thus, there was a carbon-source-dependent hierarchy in chromateamended M9 media (lactate $>$ glucose $>>$ acetate) that cannot be explained simply on the basis of better growth medium energetics since glucose supported higher cell densities than lactate in the absence of $\mathrm{Cr}(\mathrm{VI})$, yet as $\mathrm{Cr}(\mathrm{VI})$ levels increased lactate supported higher cell densities than glucose. Therefore, M9L was chosen as the minimal medium for subsequent growth studies.

To determine whether F1 is capable of chromate reduction, cells were grown in LB broth containing $\mathrm{K}_{2} \mathrm{CrO}_{4}$ and chromate reduction was measured for up to $31.5 \mathrm{~h}$. F1 reduced $0.3 \mathrm{mM} \mathrm{Cr}(\mathrm{VI})$ to $0.05 \mathrm{mM}$ or less within $25 \mathrm{~h}$ (Figure 2). The ability of F1 to carry out this reduction was largely independent of the initial cell density of the culture as evidenced by the fact that both a culture grown to mid-log phase $(\mathrm{OD}=0.5)$ prior to chromate exposure and a newly inoculated culture $(\mathrm{OD}=0.07)$ both reduced chromate to similar final concentrations (Figure 2). In addition, we tested reduction ability at $1 \mathrm{mM}$ chromate by mid-log cells and found that there was no reduction within the first $75 \mathrm{~min}$ (initial chromate concentration and concentration at 75 min measured at $0.93 \pm 0.01$ and $0.92 \pm 0.04 \mathrm{mM}$, respectively); furthermore, at this higher 


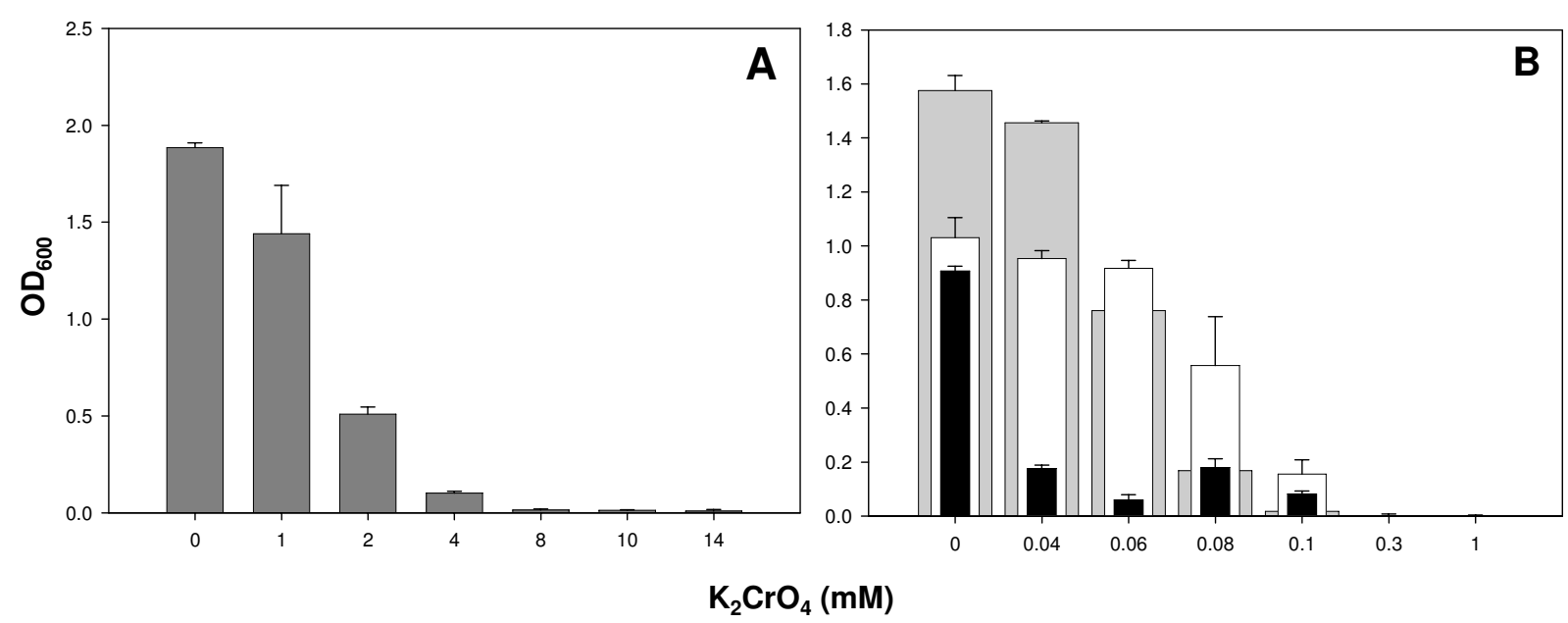

Figure 1 Effect of carbon source on MIC of chromate for P. putida F1. Optical densities $\left(\mathrm{OD}_{600}\right)$ of $\mathrm{F} 1$ cultures after 48 h of growth in the presence of varying concentrations of chromate $\left(\mathrm{K}_{2} \mathrm{CrO}_{4}\right)$ are shown. (A) F1 growth in LB broth. (B) F1 growth in $\mathrm{M} 9$ minimal media supplemented with $50 \mathrm{mM}$ glucose (grey bars), $50 \mathrm{mM}$ sodium lactate (white bars), or $67 \mathrm{mM}$ sodium acetate (black bars) as the sole source of carbon. All cultures were grown in triplicate. Error bars denote the standard deviation of replicate measurements.

initial concentration there was less reduction over a $24 \mathrm{~h}$ period (final concentration $=0.77 \mathrm{mM} \pm 0.03 \mathrm{mM}$ ).

A chromate level of $1 \mathrm{mM}$ was selected for challenging mid-log-phase LB- and M9L-grown cells, because it represented the lowest concentration tested for which cell toxicity was observed under LB conditions. Because we were interested in delineating the early molecular response to $\mathrm{Cr}(\mathrm{VI})$ exposure, the 75 -min time interval following chromate exposure was selected for harvest and analysis of F1 proteomes. Figure 3 shows the growth differences between the $\mathrm{Cr}(\mathrm{VI})$-treated and untreated cultures for the two different nutrient conditions at the collection time interval (75 min post-chromate addition) for shotgun proteomics analysis. The effect of $\mathrm{Cr}(\mathrm{VI})$ addition was greater on M9L cells, which showed a $\sim 34 \%$ reduction in cell density at the harvest point, while the growth difference between $\mathrm{Cr}(\mathrm{VI})$-treated and untreated control cells in LB liquid media was $\sim 10 \%$. No measurable $\mathrm{Cr}(\mathrm{VI})$ reduction by $\mathrm{F} 1$ was detected under either growth condition within the 75-min period of exposure, although this strain of P. putida was shown to reduce 0.3 $\mathrm{mM}$ chromate to $\sim 0 \mathrm{mM}$ over $24 \mathrm{~h}$ (Figure 2 ).

\section{Global analysis of P. putida F1 proteomes under different growth conditions}

Protein abundance measurements were compared for $\mathrm{Cr}$ (VI)-challenged and untreated $P$. putida $\mathrm{F} 1$ cells grown aerobically in either complex (LB) medium or defined minimal (M9L) medium containing lactate as the sole carbon/energy source in order to assess growth condition-dependent differences in the molecular response to acute chromate exposure as well as proteomic signatures indicative of heavy metal stress irrespective of the nutritional milieu. In general, a total of 2140 (41\%) and 2383 (45\%) functionally diverse, non-redundant proteins out of 5252 predicted proteins were detected in P. putida F1 cultivated in LB or M9L media, respectively, with and without chromate. By pooling all of the non-redundant proteins across both minimal and LB media samples, a total of 2,681 proteins were detected, which is $\sim 50 \%$ of the predicted proteome just from these four growth conditions. The entire list of identified proteins with their spectral counts and associated statistical analyses can be found in Additional file 1. A total of 946 proteins were found in all growth states and technical replicates (Additional file 2). Further analysis indicated that 257 proteins were exclusively expressed in LB-grown cell samples, while 485 proteins were unique to M9L-grown cells (Additional file 3).

Statistically significant proteins, i.e., those exhibiting at least a two-fold change in expression and an FDR $<0.01$, in LB- and M9L-cultivated control cells had a broad functional distribution (Figure 4 and Additional file 4). Not unexpectedly, control cells propagated in M9L medium, which is much less nutritionally robust than $L B$, showed a much higher proportion of protein expression in the COG categories of cell wall membrane and envelope biogenesis (m), amino acid transport and metabolism (e), and energy production and conversion (c) (Figure 4). Enzymes and transport proteins, specifically D-lactate dehydrogenase (cytochrome; Pput 4603) and L-lactate transporter (permease; Pput 4601), related to lactate utilization were only identified in cell samples grown with this carbon source (Additional file 1), which was a mix- 


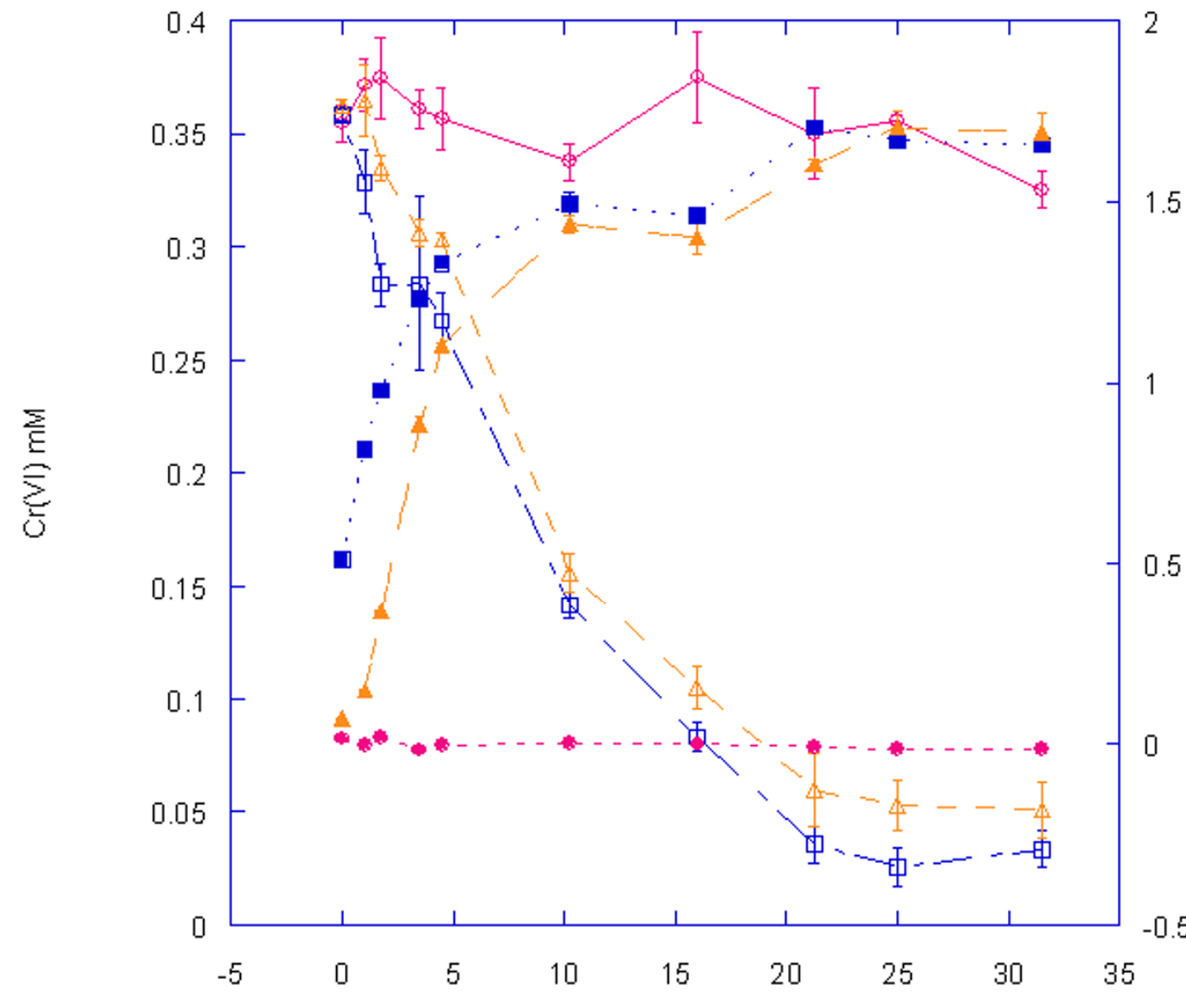

Time (h)

$$
\begin{aligned}
& \longrightarrow-\operatorname{Cr}(\mid)): \text { LB } \\
& -\square-C r(\mid)): \text { P. putida log culture } \\
& -\triangle-C r(V \mid): \text { Newly inoculated }
\end{aligned}
$$

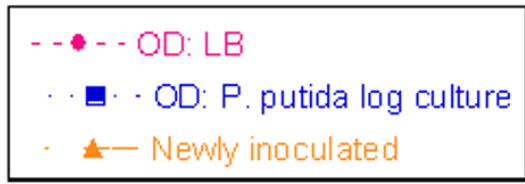

Figure 2 Chromate reduction by $P$. putida $\mathrm{F} 1$. The progression of reduction of $0.3 \mathrm{mM} \mathrm{K}_{2} \mathrm{CrO}_{4}$ by $P$. putida $\mathrm{F} 1$ in $\mathrm{LB}$ broth is shown over a $31.5 \mathrm{~h}$ period. At $\mathrm{T}=0, \mathrm{~F} 1$ cells were either freshly inoculated into the chromate-containing growth medium from an overnight culture to an OD of 0.07 (open triangles) or chromate was added to a culture of $\mathrm{F} 1$ already in mid-log phase (open squares). The abiotic control is also shown (red open circles). Each data point represents the mean of three replicate measurements. Error bars indicate one standard deviation.

ture of the D and L stereoisomers. Lactate is converted to pyruvate by lactate dehydrogenase and then is further metabolized via the tricarboxylic acid (TCA) cycle. In addition, pyruvate dehydrogenase (Pput 0594), involved in catalyzing the oxidative decarboxylation of pyruvate to acetyl-CoA and $\mathrm{CO}_{2}$, and two other enzymes of the TCA cycle, NADP-dependent isocitrate dehydrogenase (Pput 1822) and malate dehydrogenase (Pput 4958), had substantially decreased abundance levels under chromate conditions in M9L medium. The reduced synthesis of these key primary metabolic enzymes is consistent with the more severe $\mathrm{Cr}(\mathrm{VI})$-induced growth defects observed for F1 cells in M9L media (Figure 3).

Hypothetical proteins (s) and poorly characterized proteins [i.e., those with general functions ( $r$ ) or no specific function (none)] constituted the largest proportion of the two control proteome datasets, with $31 \%$ for the LB samples and 32\% for the M9L samples (Figure 4). For those genes showing no similarity to sequences with known functions, this study provides evidence of their actual expression and suggests clues to their possible biological roles in F1. Expression of proteins involved in cell motility $(\mathrm{n})$ characterized the global protein profile of M9L- 


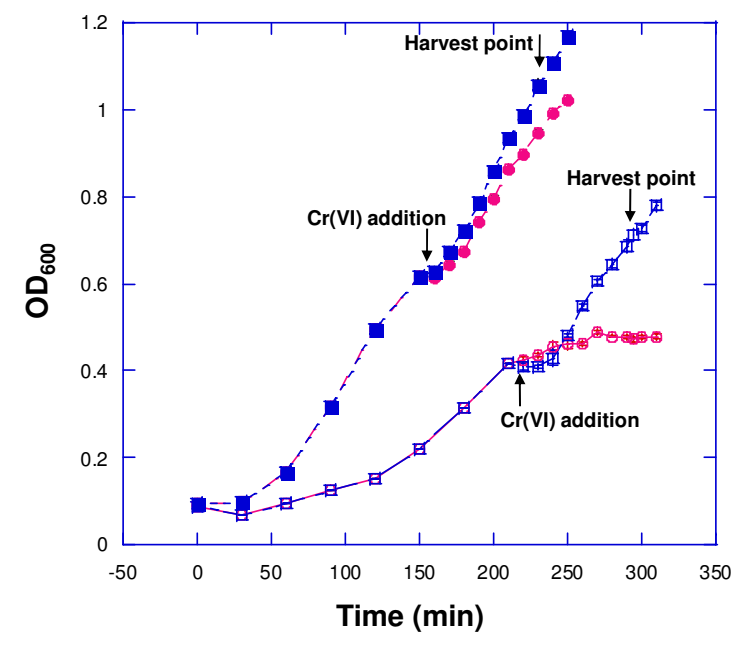

Figure 3 Impact of chromate challenge on P. putida F1 growth in $L B$ versus $M 9 L$ media. The optical densities $\left(\mathrm{OD}_{600}\right)$ of $F 1$ cultures grown aerobically under LB (closed symbols) versus defined minimal M9L media (open symbols) in either the absence or presence of $1 \mathrm{mM}$ $\mathrm{K}_{2} \mathrm{CrO}_{4}$ are shown: LB-grown cells with no chromate (closed squares), LB-grown cells with chromate added to $1 \mathrm{mM}$ at the mid-log point (closed circles), M9L-grown cells with no chromate (open squares), and M9L-grown cells with chromate added to $1 \mathrm{mM}$ at the mid-log point (open circles). The point of $\mathrm{Cr}(\mathrm{VI})$ addition and cell harvesting for proteomic analyses is presented. Each data point represents the mean of three replicate samples. Error bars indicate one standard deviation.

grown control cells but were not represented in the LB sub-proteome. Similarly, proteins belonging to the following COG categories were not identified in LB control samples: defense mechanisms (v); intracellular trafficking, secretion and vesicular transport $(\mathrm{u})$; and secondary metabolite biosynthesis, transport and catabolism (q) (Figure 4).

\section{Differential expression in chromate-stressed LB-derived proteome}

Comparative analysis of the $\mathrm{Cr}(\mathrm{VI})$-challenged and control LB samples revealed a total of 66 proteins exhibiting a significant reproducible change in abundance in response to $\mathrm{Cr}(\mathrm{VI})$ treatment, with 44 of those proteins up-regulated and 22 down-regulated (Table 1). Prominent upregulated proteins included three periplasmic binding proteins (Pput 1968, Pput 4553, Pput 0948), methyltransferase type 11 (Pput 0942), fumarate lyase (FumC, Pput 0984), the antioxidative enzyme superoxide dismutase (Fe-Mn family, Pput 0985), haem oxygenase (Pput 1042), a TonB-dependent hemoglobin/transferrin/lactoferrin family receptor (Pput 1043), a 2-oxoglutarate (2OG)- and $\mathrm{Fe}(\mathrm{II})$-dependent oxygenase (Pput 0892), and a functionally unknown two-component transcriptional regulator of the winged helix family (Pput 0287) (Table 1). Additionally, five amino acid adenylation domain-containing proteins (Pput 1624, Pput 1674-1676, and 1680) encoded within a gene cluster showed increased synthesis in response to chromate stress only under LB growth conditions (not M9L). In general, the most frequently represented COG functional group in the up-regulated LBderived proteome dataset was inorganic ion transport and metabolism (12 proteins out of 44). Proteins belonging to this role category were associated predominantly with iron homeostasis or metabolism (e.g., TonB-dependent siderophore receptors Pput 0891, 1043, 1678, 1714; haem oxygenase Pput 1042; and TonB system transport protein ExbD) (Table 1).

Down-regulated proteins constituted a small subset dominated by proteins with annotated functions in energy production and transcriptional regulation or signal transduction mechanisms (Table 1). Whereas superoxide dismutase (Pput 0985) was preferentially upregulated under $\mathrm{Cr}(\mathrm{VI})$ challenge, the relative abundance of catalase/peroxidase HPI (Pput 2061), a scavenger of hydrogen peroxide $\left(\mathrm{H}_{2} \mathrm{O}_{2}\right)$, decreased in $\mathrm{Cr}(\mathrm{VI})$-exposed cells compared to the untreated control cells. Only one protein (Pput 1123) involved in iron metabolism or homeostasis was identified as being down-regulated in the LB proteome under chromate conditions in marked contrast to the numerous proteins of similar function shown to be up-regulated under identical conditions.

\section{Differential expression in chromate-stressed M9L-derived proteome}

A total of 234 proteins exhibited statistically significant altered abundance (at least a 2-fold change and an FDR of 0.01 ) in response to acute chromate challenge under M9L growth conditions (Table 2 and Additional file 5). Among these, 95 were uniquely identified with dramatic changes in their expression levels under chromate challenge or control conditions (Table 2). Similar to the LB proteome dataset, the majority of differentially expressed proteins were identified as being up-regulated (130 proteins), while a smaller proportion (104 proteins) were down-regulated. In general, for the up-regulated sub-proteome, the most affected COG functional groups were those containing proteins of unknown function or no specific assigned function (3 proteins), as well as those with annotated functions in cell wall membrane and envelope biogenesis (17 proteins), inorganic ion transport/metabolism (14 proteins), and cell motility (16 proteins). In contrast to the differential protein profile generated under LBchromate conditions, M9L proteins grouping in the role category of inorganic ion transport/metabolism were not specifically related to Fe uptake and utilization based on sequence annotation but instead had functions in the uptake of alternative sulfur sources or unknown substrates (e.g., ABC transporter related). Prominently upregulated proteins involved in sulfur uptake and sulfur 


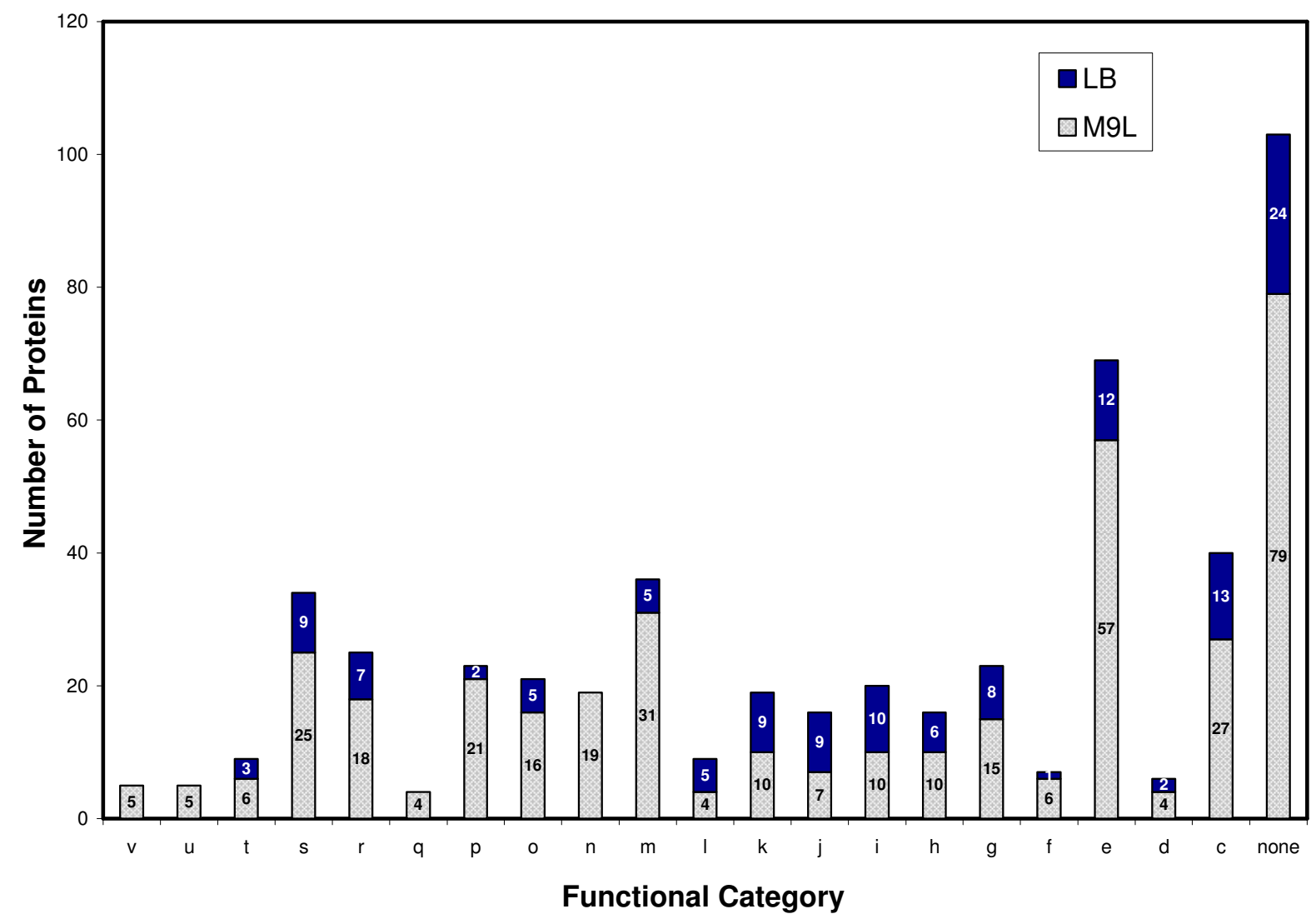

Figure 4 Functional category distribution of proteins identified from F1 cells grown in LB or M9L media in the absence of chromate. Letters along the $x$-axis refer to the following functional role categories: (v) defense mechanisms; (u) intracellular trafficking, secretion and vesicular transport; (t) signal transduction mechanisms; (s) unknown function; (r) general function prediction; (q) secondary metabolite biosynthesis, transport and catabolism; ( $p$ ) inorganic ion transport and metabolism; (o) post-translational modification, protein turnover, and chaperones; ( $n$ ) cell motility; (m) cell wall membrane and envelope biogenesis; (I) DNA replication, recombination and repair; ( $k$ ) transcription; (j) translation of ribosomal structure and biogenesis; (i) lipid transport and metabolism; (h) coenzyme transport and metabolism; (g) carbohydrate transport and metabolism; (f) nucleotide transport and metabolism; (e) amino acid transport and metabolism; (d) cell cycle control, cell division and chromosome partitioning; (c) energy production and conversion; and (none) no specific function. The number of proteins identified for each COG category under the different growth conditions is presented within the split vertical bars.

assimilatory metabolism included a taurine dioxygenase (TauD, Pput 0190), an ABC-type nitrate/sulfonate/bicarbonate transport system component (Pput 0191), and an aliphatic sulfonates family ABC transporter (Pput 2245) (Table 2 and Additional file 5). These proteins are involved in scavenging sulfur from alternative sulfur sources such as aliphatic sulfonates (e.g., taurine). Specifically, TauD catalyzes the oxygenolytic release of sulfite from taurine $[16,17]$, thereby allowing sulfonates to enter the assimilatory sulfate reduction pathway at the stage of sulfite [18].

Another conspicuous feature of the chromate-perturbed M9L proteome profile was the differential expression of proteins with functions in DNA replication, recombination and repair. An ATPase involved in DNA repair-like protein (Pput 2963), ATP-dependent DNA helicase Rep (Pput 5174), DNA repair protein RecN (Pput 4595), ribonuclease H (Pput 4172), and uracil-DNA glycosylase (Pput 4308) showed a high Poisson coefficient regression in response to chromate (Table 2 and Additional File 5). Peptides corresponding to the SOSresponse transcriptional repressor LexA (Pput 3599) were detected only in control (untreated) M9L cell samples (Table 2), suggesting that the SOS pathway of DNA repair (which protects against oxidative stress) is activated in response to chromate exposure. Along with expression of the co-chaperone Hsp20, the up-regulation of DNA recombination and repair proteins indicates the greater toxic effect of chromate imposed on M9L-grown cells.

The two most highly represented COG categories (other than unknown function) for proteins with 
Table 1: Differentially expressed proteins identified in $\mathrm{Cr}(\mathrm{VI})$-challenged LB-grown F1

\begin{tabular}{|c|c|c|c|c|}
\hline Gene ID & Functional category & Protein function & $\begin{array}{c}\text { Poisson } \\
\text { regression } \\
\text { coefficient }\end{array}$ & FDR \\
\hline Pput 4553 & Inorganic ion transport and metabolism & periplasmic binding protein & 26.59 & $3.89 \mathrm{E}-17$ \\
\hline Pput 0942 & Coenzyme transport and metabolism & Methyltransferase type 11 & 26.54 & $2.60 \mathrm{E}-16$ \\
\hline Pput 1043 & Inorganic ion transport and metabolism & $\begin{array}{l}\text { TonB-dependent hemoglobin/transferrin/ } \\
\text { lactoferrin family receptor }\end{array}$ & 25.63 & $1.59 \mathrm{E}-06$ \\
\hline Pput 4550 & Unknown Function & protein of unknown function DUF399 & 25.29 & $9.88 \mathrm{E}-05$ \\
\hline Pput 0984 & Energy production and conversion & fumarate lyase & 25.06 & $3.01 \mathrm{E}-27$ \\
\hline Pput 1680 & $\begin{array}{l}\text { Secondary metabolites biosynthesis, transport and } \\
\text { catabolism }\end{array}$ & amino acid adenylation domain & 24.97 & $1.82 \mathrm{E}-03$ \\
\hline Pput 1675 & $\begin{array}{l}\text { Secondary metabolites biosynthesis, transport and } \\
\text { catabolism }\end{array}$ & amino acid adenylation domain & 24.84 & $6.16 \mathrm{E}-08$ \\
\hline Pput 1968 & Inorganic ion transport and metabolism & periplasmic solute binding protein & 24.76 & 2.34E-07 \\
\hline Pput 1678 & Inorganic ion transport and metabolism & TonB-dependent siderophore receptor & 24.38 & 4.17E-05 \\
\hline Pput 1640 & Amino acid transport and metabolism & 2,4-diaminobutyrate 4-transaminase & 23.81 & $9.88 \mathrm{E}-08$ \\
\hline Pput 1961 & Unknown Function & MbtH domain protein & 23.60 & 2.47E-06 \\
\hline Pput 5216 & Intracellular trafficking, secretion and vesicular transport & TonB system transport protein ExbD type- 1 & 23.42 & $2.62 \mathrm{E}-05$ \\
\hline Pput 0892 & Unknown Function & 2OG-Fe(II) oxygenase & 23.24 & $1.54 \mathrm{E}-04$ \\
\hline Pput 5104 & Energy production and conversion & $\begin{array}{l}\text { Ubiquinone biosynthesis hydroxylase, UbiH/ } \\
\text { UbiF/VisC/COQ6 family }\end{array}$ & 22.97 & $1.82 \mathrm{E}-03$ \\
\hline Pput 3040 & Cell Motility & hypothetical protein & 22.78 & $1.55 \mathrm{E}-07$ \\
\hline Pput 0943 & none & lipopolysaccharide kinase & 22.76 & $7.08 \mathrm{E}-03$ \\
\hline Pput 0603 & Unknown Function & hypothetical protein & 22.76 & $7.08 \mathrm{E}-03$ \\
\hline Pput 1679 & Unknown Function & protein of unknown function DUF323 & 22.76 & $7.08 \mathrm{E}-03$ \\
\hline Pput 3610 & Cell wall membrane and envelope biogenesis & Lytic transglycosylase, catalytic & 22.76 & $7.08 \mathrm{E}-03$ \\
\hline Pput 1973 & $\begin{array}{l}\text { Secondary metabolites biosynthesis, transport and } \\
\text { catabolism }\end{array}$ & $\begin{array}{l}\text { Lysine/ornithine } \mathrm{N} \text {-monooxygenase-like } \\
\text { protein }\end{array}$ & 22.76 & 2.34E-07 \\
\hline Pput 0636 & Coenzyme transport and metabolism & aminotransferase class-III & -0.73 & $9.20 \mathrm{E}-03$ \\
\hline Pput 3436 & Carbohydrate transport and metabolism & methylisocitrate lyase & -0.74 & $6.72 \mathrm{E}-03$ \\
\hline Pput 0936 & Energy production and conversion & $\begin{array}{l}\text { hydro-lyase, Fe-S type, tartrate/fumarate } \\
\text { subfamily, alpha subunit }\end{array}$ & -0.76 & $2.05 \mathrm{E}-12$ \\
\hline Pput 2460 & $\begin{array}{l}\text { Post translational modification and protein turnover } \\
\text { chaperones }\end{array}$ & heat shock protein Hsp20 & -0.80 & 1.67E-03 \\
\hline Pput 1617 & Energy production and conversion & cytochrome c oxidase, cbb3-type, subunit II & -0.90 & $1.30 \mathrm{E}-05$ \\
\hline Pput 1610 & Energy production and conversion & cytochrome c oxidase, cbb3-type, subunit III & -0.92 & $4.85 \mathrm{E}-05$ \\
\hline Pput 1615 & Energy production and conversion & cytochrome c oxidase, cbb3-type, subunit III & -0.92 & 2.47E-06 \\
\hline Pput 1123 & Inorganic ion transport and metabolism & bacterioferritin & -1.06 & $9.58 \mathrm{E}-03$ \\
\hline Pput 2593 & Lipid transport and metabolism & 3-oxoacid CoA-transferase, B subunit & -1.16 & $3.81 \mathrm{E}-03$ \\
\hline Pput 4498 & Lipid transport and metabolism & acetyl-CoA acetyltransferase & -1.23 & 3.34E-07 \\
\hline Pput 4329 & Amino acid transport and metabolism & $\begin{array}{l}\text { thiamine pyrophosphate enzyme TPP } \\
\text { binding domain protein }\end{array}$ & -1.25 & 4.49E-03 \\
\hline Pput 1388 & Amino acid transport and metabolism & putative agmatinase & -1.82 & $8.75 \mathrm{E}-11$ \\
\hline Pput 0143 & Energy production and conversion & cytochrome c, class I & -1.84 & $5.95 \mathrm{E}-09$ \\
\hline Pput 2061 & Inorganic ion transport and metabolism & catalase/peroxidase HPI & -2.01 & 8.74E-07 \\
\hline Pput 3734 & Energy production and conversion & NADH:flavin oxidoreductase/NADH oxidase & -2.60 & 1.37E-04 \\
\hline Pput 2594 & Lipid transport and metabolism & 3-oxoacid CoA-transferase, A subunit & -3.14 & 7.15E-09 \\
\hline
\end{tabular}


Table 1: Differentially expressed proteins identified in $\mathrm{Cr}(\mathrm{VI})$-challenged LB-grown F1 (Continued)

\begin{tabular}{|c|c|c|c|c|}
\hline Pput 2025 & Transcription & transcriptional regulator, GntR family & -19.95 & $9.31 \mathrm{E}-03$ \\
\hline Pput 1948 & none & cytochrome c, class I & -22.49 & 1.37E-04 \\
\hline Pput 1559 & Transcription & $\begin{array}{l}\text { putative transcriptional regulator, AsnC } \\
\text { family }\end{array}$ & -22.95 & $9.31 \mathrm{E}-03$ \\
\hline Pput 2382 & Energy production and conversion & Gluconate 2-dehydrogenase & -23.20 & $1.83 \mathrm{E}-03$ \\
\hline Pput 3735 & Transcription & $\begin{array}{l}\text { AraC-type transcriptional regulator domain } \\
\text { protein }\end{array}$ & -24.08 & 4.39E-03 \\
\hline Pput 1496 & Signal transduction mechanisms & $\begin{array}{l}\text { Two-component, sigma54 specific, } \\
\text { transcriptional regulator, Fis family }\end{array}$ & -24.95 & $9.31 \mathrm{E}-03$ \\
\hline
\end{tabular}

FDR: False Discovery Rate

Table 1 lists top 20 up-regulated and down-regulated proteins in LB-grown chromate shocked cells of $P$. putida when compared to unstressed LB grown cells. Poisson regression coefficient score and False Discovery Rate (FDR) of $1 \%$ were used for analyzing expression levels of the proteins.

decreased abundance were associated with amino acid transport and metabolism (14 proteins) and energy production and conversion (17 proteins). A number of the down-regulated energy metabolism proteins had annotated functions associated with electron transport chain processes and included a proton-translocating NADHquinone oxidoreductase (Pput 1736) and a cytochrome c (Pput 1947). It is also interesting to note that a NADPHdependent FMN reductase (Pput 1727), which exhibits $100 \%$ amino acid sequence identity to the chromate reductase ChrR from $P$. putida strain KT2440, was detected at negligible levels in untreated (control) cell samples but was down-regulated in response to acute chromate treatment under M9L and LB growth conditions (Additional file 1). ChrR is a soluble dimeric flavin mononucleotide-binding flavoprotein that was shown to catalyze full reduction of $\mathrm{Cr}$ (VI) to $\mathrm{Cr}(\mathrm{III})$ [19] and more recently, was demonstrated to exhibit quinone reductase activity, of importance in protecting $P$. putida cells against $\mathrm{H}_{2} \mathrm{O}_{2}$ stress [20].

\section{Growth media-independent proteomic responses to chromate}

We compared the $\mathrm{Cr}(\mathrm{VI})$-perturbed proteome profiles for LB- and M9L-grown P. putida F1 cells to identify shared molecular signatures (biomarkers) indicative of chromate stress. Comparative analysis indicated that eleven proteins detected only in $\mathrm{Cr}(\mathrm{VI})$-treated cells were common for the two different growth conditions (Additional file 6). Of these eleven chromate-responsive proteins, seven were determined to be statistically significant based on an FDR cutoff of 0.05 and consisted of a twocomponent transcriptional regulator of the winged helix family (Pput 0287), fumarate lyase (Pput 0984), superoxide dismutase (Pput 0985), a TonB-dependent hemoglobin/transferrin/lactoferrin family receptor (Pput 1043), 4hydroxythreonine-4-phosphate dehydrogenase (Pput 0436), a FAD-dependent oxidoreductase (Pput 5183) and ribosomal protein L36 (Pput 0508) (Table 3). The functional diversity of these seven proteins, which represent six different COG categories, indicates the complexity of the core cellular response to chromate insult, a response that is likely complicated by secondary or indirect effects. In addition, the very limited subset of shared proteins suggests that growth conditions substantially influence the global molecular response to chromate.

\section{Discussion}

This global proteomic study was undertaken to interrogate growth media-based differences in the P. putida F1 molecular response to the stress of the oxyanion chromate, a widespread anthropogenic contaminant and a current focus of bioremediation efforts by the DOE. The ultimate aim was to identify proteome changes reflective of, although not necessarily specific to, early chromate stress in microbial cells irrespective of the nutritional environment. Our physiological investigations indicated that the impact of chromate toxicity was largely dependent on the growth medium. Rich (LB) medium, for example, was able to support F1 growth at input chromate concentrations at least 40-fold greater than any of the defined minimal M9-based media. Presently, it is not known whether this observation was due to differences in growth rate as a function of the medium [the initial growth rate of F1 was 3 to 5 times faster in LB than in M9 media (data not shown)], a higher bioavailability of $\mathrm{Cr}(\mathrm{VI})$ in minimal media, or a lack of sequestration of toxic reduced chromium forms by organic molecules in the media. Comparative analysis of the proteomic profiles generated in this study revealed that acute chromate exposure affects, either directly or indirectly, a wide range of cellular processes and functions, with some of the most profound changes in expression occurring among proteins with annotated functions in inorganic ion transport, amino acid transport and metabolism, cell wall membrane and envelope biogenesis, and energy production. 
Table 2: Selected differentially expressed proteins detected in $\mathrm{Cr}(\mathrm{VI})$-challenged M9L-grown F1

\begin{tabular}{|c|c|c|c|c|}
\hline Gene ID & Functional category & Protein function & $\begin{array}{l}\text { Poisson } \\
\text { regression } \\
\text { coefficient }\end{array}$ & FDR \\
\hline Pput 0191 & Inorganic ion transport and metabolism & $\begin{array}{l}\text { ABC-type nitrate/sulfonate/bicarbonate transport } \\
\text { systems periplasmic components-like protein }\end{array}$ & 26.45 & $3.65 \mathrm{E}-14$ \\
\hline Pput 0190 & Secondary metabolites biosynthesis & Taurine dioxygenase & 25.54 & $2.01 \mathrm{E}-15$ \\
\hline Pput 4621 & none & hypothetical protein & 25.52 & $8.56 \mathrm{E}-06$ \\
\hline Pput 1872 & Cell Motility & methyl-accepting chemotaxis sensory transducer & 24.87 & $2.68 \mathrm{E}-03$ \\
\hline Pput 0391 & Coenzyme transport and metabolism & biotin biosynthesis protein BioC & 24.69 & $8.28 \mathrm{E}-07$ \\
\hline Pput 3604 & Unknown Function & protein of unknown function DUF1653 & 24.67 & 7.60E-03 \\
\hline Pput 1104 & Transcription & transcriptional regulator, LysR family & 24.67 & $7.60 \mathrm{E}-03$ \\
\hline Pput 2545 & Transcription & transcriptional regulator, LysR family & 24.67 & 7.60E-03 \\
\hline Pput 2963 & Replication & ATPase involved in DNA repair-like protein & 24.67 & $7.60 \mathrm{E}-03$ \\
\hline Pput 4712 & $\begin{array}{l}\text { Post translational modification and protein } \\
\text { turnover chaperones }\end{array}$ & band 7 protein & 24.67 & $7.60 \mathrm{E}-03$ \\
\hline Pput 1882 & Amino acid transport and metabolism & $\mathrm{ABC}$ transporter related & 24.67 & $1.80 \mathrm{E}-04$ \\
\hline Pput 1060 & Carbohydrate transport and metabolism & glucose-6-phosphate 1-dehydrogenase & 24.25 & $3.38 \mathrm{E}-10$ \\
\hline Pput 0247 & Inorganic ion transport and metabolism & $\mathrm{ABC}$ transporter related & 24.11 & 4.50E-03 \\
\hline Pput 0999 & Secondary metabolites biosynthesis & Mammalian cell entry related domain protein & 23.78 & 4.50E-03 \\
\hline Pput 4172 & Replication & Ribonuclease $\mathrm{H}$ & 23.78 & $4.50 \mathrm{E}-03$ \\
\hline Pput 3319 & none & fatty acid cistrans isomerase & 23.78 & $4.50 \mathrm{E}-03$ \\
\hline Pput 0949 & Energy production and conversion & protein of unknown function DUF1111 & 23.78 & $4.50 \mathrm{E}-03$ \\
\hline Pput 4281 & Coenzyme transport and metabolism & putative methyltransferase & 23.78 & 4.50E-03 \\
\hline Pput 3991 & $\begin{array}{l}\text { Cell wall membrane and envelope } \\
\text { biogenesis }\end{array}$ & MscS Mechanosensitive ion channel & 23.78 & 4.50E-03 \\
\hline Pput 5174 & Replication & ATP-dependent DNA helicase Rep & 23.78 & 4.50E-03 \\
\hline Pput 2568 & Amino acid transport and metabolism & FAD dependent oxidoreductase & -22.82 & $2.99 \mathrm{E}-07$ \\
\hline Pput 1812 & General function prediction & alpha/beta hydrolase fold & -23.83 & 2.79E-03 \\
\hline Pput 4237 & Amino acid transport and metabolism & spermidine/putrescine $A B C$ transporter ATPase subunit & -23.94 & 7.11E-29 \\
\hline Pput 2061 & Inorganic ion transport and metabolism & catalase/peroxidase HPI & -24.23 & 2.03E-04 \\
\hline Pput 1736 & Energy production and conversion & $\begin{array}{l}\text { proton-translocating NADH-quinone oxidoreductase, } \\
\text { chain } \mathrm{L}\end{array}$ & -24.31 & $1.13 \mathrm{E}-12$ \\
\hline Pput 0594 & Energy production and conversion & Pyruvate dehydrogenase (acetyl-transferring) & -24.40 & $1.48 \mathrm{E}-14$ \\
\hline Pput 3083 & Energy production and conversion & aldehyde dehydrogenase & -24.55 & $5.31 \mathrm{E}-03$ \\
\hline Pput 0110 & General function prediction & $\begin{array}{l}\text { Carbonic anhydrase/acetyltransferase isoleucine patch } \\
\text { superfamily-like protein }\end{array}$ & -24.82 & $5.31 \mathrm{E}-03$ \\
\hline Pput 4889 & Amino acid transport and metabolism & phosphoribosyl-ATP pyrophosphohydrolase & -24.82 & 1.47E-03 \\
\hline Pput 0527 & Amino acid transport and metabolism & L-seryl-tRNA(Sec) selenium transferase & -25.04 & $3.99 \mathrm{E}-04$ \\
\hline Pput 4915 & Carbohydrate transport and metabolism & glycogen/starch/alpha-glucan phosphorylase & -25.23 & 2.03E-04 \\
\hline Pput 1789 & None & hypothetical protein & -25.31 & 5.33E-06 \\
\hline Pput 0932 & General function prediction & intracellular protease, Pfpl family & -25.63 & $2.52 \mathrm{E}-06$ \\
\hline Pput 2569 & None & hypothetical protein & -25.68 & $2.52 \mathrm{E}-06$ \\
\hline Pput 4267 & General function prediction & transferase hexapeptide repeat containing protein & -25.68 & $2.52 \mathrm{E}-06$ \\
\hline Pput 1947 & Energy production and conversion & cytochrome c, class I & -25.68 & $1.31 \mathrm{E}-06$ \\
\hline Pput 2567 & Amino acid transport and metabolism & extracellular solute-binding protein, family 1 & -25.74 & 7.04E-08 \\
\hline
\end{tabular}


Table 2: Selected differentially expressed proteins detected in $\mathrm{Cr}$ (VI)-challenged M9L-grown F1 (Continued)

\begin{tabular}{lllr}
\hline Pput 2463 & $\begin{array}{l}\text { Cell wall membrane and envelope } \\
\text { biogenesis }\end{array}$ & GCN5-related N-acetyltransferase & -25.92 \\
Pput 0592 & Energy production and conversion & alpha/beta hydrolase fold & $3.86 \mathrm{E}-09$ \\
Pput 1187 & None & hypothetical protein & -26.07 \\
\hline FDR: False Discovery Rate & -26.11 & $3.65 \mathrm{E}-14$ \\
The table shows top 20 up-regulated and down-regulated proteins in Cr-shocked, M9L-grown cells of $P$. putida when compared to unstressed \\
M9L cells. Proteome datasets were analyzed using the Poisson regression model combined with False Discovery Rate (FDR) of 1\%.
\end{tabular}

Certain hallmark features of the bacterial molecular response to chromate challenge are emerging with the increasing availability of transcriptomic and proteomic descriptions of $\mathrm{Cr}(\mathrm{VI})$-challenged microorganisms. Comparative analysis of the LB- and M9L-derived proteomes described here revealed that an adaptive strategy employed by $P$. putida F1 in response to acute chromate exposure was up-regulation of proteins involved in sulfate transport (sulfate ABC transporter Pput 1565), cysteine biosynthesis (Pput 4421 and 4422 encoding sulfate adenylyltransferase large and small subunits, respectively), and the uptake and utilization of alternative sulfur sources such as aliphatic sulfonates (taurine dioxygenase Pput 0190 and ABC-type nitrate/sulfonate/bicarbonate transport systems protein Pput 0191) (Additional file 1 and Table 2). Because of its structural similarity to $\mathrm{SO}_{4}{ }^{2-}$, exogenous chromate $\left(\mathrm{CrO}_{4}{ }^{2-}\right)$ competes with sulfate for transport across bacterial cell membranes via sulfate anion transport systems [21-24], leading to low internal levels of sulfur. Up-regulation of genes/proteins with annotated functions in sulfur transport and metabolism has been observed in other chromate-stressed Gammaproteobacteria [25-27] as well as in the highly chromate-resistant Arthrobacter sp. strain FB24, a high G + C actinobacterium [28]. Using two-dimensional gel electrophoretic analysis, Ackerley et al. [25] showed that chromate-challenged nonadapted $E$. coli $\mathrm{K}-12$ cells contained increased abundance levels of CysK and CysN, while challenged pre-adapted cells expressed alkane sulfonate monooxygenase, which functions by converting alkane sulfonates to sulfite and aldehyde. Similarly, multidimensional HPLC-MS/MS analysis of Shewanella oneidensis MR-1 exposed to different sub-lethal concentrations of chromate demonstrated increased abundance of cysteine synthase A (CysK), sulfate adenylyltransferase (CysD and CysN), adenylylsulfate kinase (CysC), sulfite reductase (CysI), and periplasmic sulfate-binding protein (Sbp) $[26,27]$. A recent study investigating chromate resistance in Pseudomonas corrugata 28, a Cr(VI)-hyper-resistant (MIC, $40 \mathrm{mM} \mathrm{K}{ }_{2} \mathrm{CrO}_{4}$ ) bacterium, demonstrated that $\mathrm{Cr}(\mathrm{VI})$ susceptibility was attributed to insertional inactivation of oscA, which encodes a hypothetical small protein of unknown function and is located in a gene cluster with components of the sulfate $\mathrm{ABC}$ transporter system
[29]. We previously reported that S. oneidensis SO4651, a homolog of OscA [29], was up-regulated at both the transcript and protein levels during the entry response to $\mathrm{Cr}(\mathrm{VI})$ stress [26]. Viti et al. [29] showed that the P. corrugata $o s c A-s b p$ transcriptional unit was strongly overexpressed after chromate exposure, thus lending further support for the link between sulfate starvation and $\mathrm{Cr}(\mathrm{VI})$ stress response. Sufficient cysteine availability is critical not only for protein biosynthesis but also in the defense against metal-induced oxidative stress by maintaining cellular redox homeostasis through the production of protective thiol-containing compounds such as glutathione. Therefore, the up-regulation of genes/proteins involved in sulfur transport and metabolism constitutes a major and conserved cellular response among Gammaproteobacteria to the oxidative burden imposed by chromate challenge.

Reduced P. putida F1 growth rates and higher sensitivity to chromate in M9L medium may be attributable to stress resulting from low intracellular sulfate levels as well as high intracellular chromate levels. The sole source of sulfate in M9L medium is $\mathrm{MgSO}_{4}$, which is likely transported into the cell by the sulfate active transport system. This transport system has been shown in other Pseudomonas species to be principally responsible for the uptake of chromate [24]. As already mentioned, chromate is a competitive inhibitor of sulfate uptake [24]. Reduced sulfate uptake is compensated for by increased uptake of cysteine and cysteine-containing compounds (as well as other sulfur-containing compounds) through alternative transporter systems not competitively inhibited by chromate. Cysteine is freely available in complex LB medium but not in M9L medium. The reduced availability of cysteine in M9L medium could have resulted in lower levels of intracellular cysteine needed for important cellular biosynthetic processes, leading to the more striking reduced growth rates and chromate sensitivity of cells cultivated in M9L medium compared to LB medium.

Chromate toxicity has been attributed primarily to oxidative stress generated by the intracellular reduction of $\mathrm{Cr}(\mathrm{VI})$ to the transient highly reactive radical $\mathrm{Cr}(\mathrm{V})$, which redox cycles and thereby creates reactive oxygen species (ROS) $[22,25,30]$. ROS production leads to the damage of such cellular components as DNA and pro- 
teins. Presumably to counter $\mathrm{Cr}(\mathrm{VI})$-induced oxidative stress, synthesis of the antioxidant defense protein $\mathrm{Mn} /$ Fe-binding superoxide dismutase (Sod; Pput 0985), which catalyzes decomposition of superoxide anion $\left(\mathrm{O}_{2}{ }^{-}\right)$to hydrogen peroxide and molecular oxygen, was detected only in $\mathrm{Cr}(\mathrm{VI})$-exposed LB- and M9L-grown P. putida F1 cells. Similarly, the up-regulation of Sod at the transcript or protein level was observed for $\mathrm{Cr}(\mathrm{VI})$-stressed E. coli [25] and the Alphaproteobacterium Caulobacter crescentus [31] but not for S. oneidensis MR-1 cells subjected to an acute chromate treatment [26]. Instead, katG-1 (catalase/peroxidase hydroperoxidase) and $k a t B$ (catalase) were preferentially induced at $\mathrm{Cr}(\mathrm{VI})$ exposure time intervals of 60 and $90 \mathrm{~min}$. Based on our proteomic analyses, the enhancement of free-radical detoxifying activities constitutes a vital cellular defense mechanism against chromate toxicity in P. putida $\mathrm{F} 1$ regardless of the growth medium, whereas cellular defenses against $\mathrm{H}_{2} \mathrm{O}_{2}$ (i.e., increased expression of catalase) were not required during the early stages of chromate exposure in contrast to that observed for S. oneidensis MR-1.

Located immediately upstream of the F1 sod gene is fumC (Pput 0984), which also was identified only in $\mathrm{Cr}(\mathrm{VI})$-stressed cells under both growth media conditions (Table 3). The gene synteny is similar (but not identical) to that found in the genome of Pseudomonas aeruginosa, in which an $\mathrm{O}_{2}$ - resistant isoform of fumarase (or fumarate hydratase/lyase) is linked to downstream genes $\operatorname{orf} X$ (of unknown function) and $\operatorname{sod} A$ (encodes Mn-cofactored Sod) in an iron-responsive operon [32]. Fumarase catalyzes the reversible conversion of fumarate to malate in the TCA cycle and has been shown to be upregulated under iron-limiting conditions in $P$. aeruginosa [33]. It remains to be determined whether expression of P. putida F1 FumC exclusively in $\mathrm{Cr}(\mathrm{VI})$-challenged cells is part of an iron starvation response.

As previously demonstrated for S. oneidensis MR-1 $[26,27]$ and C. crescentus [31], another prominent characteristic of the cellular response to acute chromate exposure is the up-regulation of genes/proteins with functions in iron acquisition and homeostasis, namely TonBdependent receptors and siderophore biosynthesis proteins. Similarly, TonB-dependent receptors for high-affinity iron chelators were a conspicuous feature of upregulated, $\mathrm{Cr}(\mathrm{VI})$-perturbed $P$. putida sub-proteomes, particularly under LB growth conditions. The increased abundance of four such outer membrane receptors under LB-Cr(VI) conditions is likely connected with the concomitant up-regulation of five amino acid adenylation domains. The adenylation (A) domains represent the active core of each modular unit comprising large multifunctional enzymes termed nonribosomal peptide synthetases [34]. The A domain functions by recognizing a specific amino or hydroxyl acid substrate and activating it as aminoacyl adenylate via ATP hydrolysis. While nonribosomal peptide synthetases can produce peptides of broad and sometimes obscure biological activity, these multidomain enzymes are known to be involved in the assembly of aryl-capped peptide and peptide-polyketide siderophores from Pseudomonas spp. [35,36]. Furthermore, expression of a TonB-dependent hemoglobin/ transferrin/lactoferrin family receptor (Pput 1043) as part of the media-independent core molecular response to chromate exposure points to iron availability and homeostasis as playing an important role in the cellular adaptation of $\mathrm{F} 1$ to chromate stress.

Earlier reports revealed a distinct link between cell sensitivity to chromate and iron availability. It was observed, for example, that ton $B$ mutants of $E$. coli exhibited increased sensitivity to chromium salts [37-39], which could be relieved by adding iron to the growth medium [38]. More recently, siderophores produced by certain Pseudomonas species were shown to bind exogenous transition metals other than $\mathrm{Fe}(\mathrm{III})$ with appreciable affinity [40,41], thus invoking conditions of low internal iron. The siderophore pyridine-2,6-bis(thiocarboxylic acid) (pdtc) from Pseudomonas stutzeri KC, for example, has been shown to detoxify extracellular chromium(VI), selenium, and tellurium oxyanions, suggesting that pdtc functions not only in iron acquisition but also in an initial line of defense against metal toxicity [42,43]. Research is required to delineate the physiological basis for the increased expression of iron acquisition receptors in response to acute chromate stress.

The $\mathrm{Cr}(\mathrm{VI})$-responsive proteomic subset shared between the two different growth conditions consisted mostly of structural proteins with the exception of one regulatory protein, annotated as a two-component response regulator (Pput 0287) belonging to the winged helix-turn-helix family of DNA-binding regulators. Prototypical two-component systems, which constitute the predominant mechanism used by bacteria for coupling environmental signals to specific adaptive responses, comprise a sensor histidine kinase and a cognate response regulator $[44,45]$. The regulatory targets for the $P$. putida response regulator have not previously been identified. A similar observation was noted for $\mathrm{Cr}(\mathrm{VI})$ stressed S. oneidensis MR-1 cells in which a DNA-binding response regulator (designated SO2426), also of the OmpR/PhoB subfamily [46] of winged-helix DNA-binding domains, was detected at the protein level only in chromate-challenged cells [26,27]. Further in-depth functional analysis using a $\Delta$ so2426 mutant strain found that this two-component response regulator likely is involved in the activation of genes required for siderophore-mediated iron acquisition [47]. A DNA-binding response regulator consisting of a CheY-like receiver domain also was 
Table 3: Statistically significant proteins detected only under $\mathrm{Cr}(\mathrm{VI})$ conditions in LB- and M9L-grown F1

\begin{tabular}{|c|c|c|c|c|c|c|}
\hline \multirow[b]{2}{*}{ Gene ID } & \multirow[b]{2}{*}{ Protein Function } & \multirow[b]{2}{*}{ Functional category } & \multicolumn{4}{|c|}{ Spectral Countsa } \\
\hline & & & Control LB & Control M9L & $\begin{array}{c}\mathrm{Cr}(\mathrm{VI}) \\
\text { LB }\end{array}$ & $\mathrm{Cr}(\mathrm{VI}) \mathrm{M} 9 \mathrm{~L}$ \\
\hline Pput 0287 & $\begin{array}{l}\text { two component } \\
\text { transcriptional regulator }\end{array}$ & Transcription & 0 & 0 & 8 & 4.5 \\
\hline Pput 0436 & $\begin{array}{l}\text { 4-hydroxythreonine-4- } \\
\text { phosphate dehydrogenase }\end{array}$ & $\begin{array}{l}\text { Coenzyme transport } \\
\text { and metabolism }\end{array}$ & 0 & 0 & 4.5 & 7 \\
\hline Pput 0508 & ribosomal protein L36 & $\begin{array}{l}\text { Translation of } \\
\text { ribosomal structure } \\
\text { and biogenesis }\end{array}$ & 0 & 0 & 4.5 & 7.5 \\
\hline Pput 0984 & fumarate lyase & $\begin{array}{l}\text { Energy production } \\
\text { and conversion }\end{array}$ & 0 & 0 & 64.5 & 7.5 \\
\hline Pput 0985 & Superoxide dismutase & $\begin{array}{l}\text { Inorganic ion } \\
\text { transport and } \\
\text { metabolism }\end{array}$ & 0 & 0 & 13 & 4 \\
\hline Pput 1043 & $\begin{array}{l}\text { TonB-dependent } \\
\text { hemoglobin/transferrin/ } \\
\text { lactoferrin family receptor }\end{array}$ & $\begin{array}{l}\text { Inorganic ion } \\
\text { transport and } \\
\text { metabolism }\end{array}$ & 0 & 0 & 15.5 & 3.5 \\
\hline Pput 5183 & $\begin{array}{l}\text { FAD dependent } \\
\text { oxidoreductase }\end{array}$ & $\begin{array}{l}\text { Amino acid transport } \\
\text { and metabolism }\end{array}$ & 0 & 0 & 6.5 & 3 \\
\hline
\end{tabular}

aspectral counts refer to the average spectral counts from two independent MS runs with an FDR cutoff of 0.05 .

The table lists proteins common to chromate stressed, M9L and LB grown cells. The proteins were selected on the basis of their Poisson regression score and an FDR of 0.05 . Spectral counts for each protein show the proteins to be uniquely expressed in chromate-stressed cells only.

up-regulated (at the transcript level) in $\mathrm{Cr}(\mathrm{VI})$-treated $C$. crescentus [31]. At this point, it is not known whether expression of Pput 0287 is part of a cellular regulatory system for sensing external toxic metals or a secondary effect of $\mathrm{Cr}(\mathrm{VI})$ challenge.

\section{Conclusions}

In summary, effective bioremediation strategies should encompass an understanding of the fundamental physiological and molecular processes extant in the remediating populations. Ideally, one would like to perform such studies in the most ecologically relevant context, but the trade-off is that in situ it is difficult to control enough variables to make the results interpretable. As described here, we have monitored growth and proteome expression in the laboratory under disparate but controlled nutrient conditions ranging from the less (a rich medium) to the more ecologically relevant (minimal medium). We have shown that a strain of P. putida, F1, well-known for its ability to degrade aromatic xenobiotics, is also resistant to low $\mathrm{mM}$ levels of $\mathrm{Cr}(\mathrm{VI})$ and is capable of reducing hexavalent chromium. Furthermore, the proteome expressed in response to acute chromate challenge is dependent upon factors other than just the presence of external chromate. Most importantly, we have identified in this study a core set of proteins that are differentially expressed in response to $\mathrm{Cr}(\mathrm{VI})$ challenge that appear to be media-independent, and this core protein subset will serve as a baseline for comparison with future proteomic analyses of $P$. putida-containing microbial communities in naturally occurring $\mathrm{Cr}(\mathrm{VI})$-contaminated soils.

\section{Methods}

\section{Strains, media, and growth conditions}

Pseudomonas putida strain F1 (ATCC 700007) was grown aerobically at $30^{\circ} \mathrm{C}$ with vigorous shaking (200 rpm) in either Luria-Bertani (LB) medium or M9 minimal medium $\left[2 \mathrm{mM} \mathrm{MgSO}_{4}, 0.1 \mathrm{mM} \mathrm{CaCl}_{2}\right.$, and $1 \mathrm{X} \mathrm{M9}$ salts (5X M9 salts contains per liter: $15 \mathrm{~g} \mathrm{KH}_{2} \mathrm{PO}_{4}, 2.5 \mathrm{~g}$ $\left.\left.\mathrm{NaCl}, 5 \mathrm{~g} \mathrm{NH} \mathrm{N}_{4} \mathrm{Cl}, 64 \mathrm{~g} \mathrm{Na}_{2} \mathrm{HPO}_{4} 7 \mathrm{H}_{2} \mathrm{O}\right)\right]$ supplemented with $50 \mathrm{mM}$ (final concentration) of glucose, sodium lactate, or sodium acetate. Cultures of $P$. putida F1 were initially propagated in LB broth and then were passed twice (preconditioned) through M9 media amended with the appropriate carbon source prior to experiments using those media. The water used in these experiments was purified using a NANOpure Diamond system (Barnstead 
International, Dubuque, IA) and sterilized by autoclaving or passage through a $0.2 \mu \mathrm{m}$ filter (VWR, West Chester, PA).

To determine the minimal inhibitory concentration (MIC) of $\mathrm{Cr}(\mathrm{VI})$ for $P$. putida $\mathrm{F} 1$ growth in rich and minimal media, five ml of LB broth or M9 medium plus a single carbon source $(50 \mathrm{mM}$ glucose, sodium lactate, or sodium acetate) was inoculated with a freezer stock of preconditioned $P$. putida $\mathrm{F} 1$ and grown overnight at $30^{\circ} \mathrm{C}$ with constant shaking at $200 \mathrm{rpm}$. Cultures containing growth medium and increasing concentrations of $\mathrm{K}_{2} \mathrm{CrO}_{4}$ were inoculated to obtain an initial optical density at 600 $\mathrm{nm}\left(\mathrm{OD}_{600}\right)$ of $\sim 0.04$ using 16-h overnight cultures as inocula. End-point turbidity measurements were recorded after $48 \mathrm{~h}$ of growth, and all MIC determinations were performed using three biological replicates.

For comparative proteomic analysis of chromatetreated cells in complex versus defined minimal media, five $\mathrm{ml}$ of LB or M9L (M9 medium plus $50 \mathrm{mM}$ sodium lactate) were inoculated with a freezer stock of preconditioned P. putida $\mathrm{F} 1$ and grown overnight. These cultures were used to inoculate $300 \mathrm{ml}$ of the same medium in $1 \mathrm{~L}$ flasks to an optical density of $\sim 0.008 \mathrm{OD}_{600}$ units. Cells were incubated at $30^{\circ} \mathrm{C}$ with constant shaking $(200 \mathrm{rpm})$ until cultures reached mid-log phase $\left(\mathrm{OD}_{600} \sim 0.4\right.$ for $\mathrm{M} 9 \mathrm{~L}$ and $\mathrm{OD}_{600} \sim 0.6$ for $\left.\mathrm{LB}\right)$. Cultures were divided into two equal fractions: $\mathrm{K}_{2} \mathrm{CrO}_{4}$ was added to one fraction to a final concentration of $1 \mathrm{mM}$, while the other fraction served as the untreated (no chromate) control. Incubations were then continued under the same conditions for an additional $75 \mathrm{~min}$ after which time the cells were harvested by centrifugation at $3,000 \times g$ for $10 \mathrm{~min}$ at $4^{\circ} \mathrm{C}$. The supernatant was decanted and the cell pellet was resuspended in $100 \mathrm{ml}$ of sterile $1 \times$ PBS buffer. The centrifugation and suspension were repeated as described prior to storage at $-80^{\circ} \mathrm{C}$ until needed for proteome analysis.

\section{Chromate reduction assay}

Chromate reduction levels were measured as described by Shmieman et al. [48]. Standards were prepared by the addition of $\mathrm{K}_{2} \mathrm{CrO}_{4}$ to sterile growth medium (LB medium, or M9 amended with one of the carbon sources described above) to final concentrations ranging from 0.1 to $1.0 \mathrm{mM}$ (in $0.1 \mathrm{mM}$ increments). A ChromaVer3 pillow was added to $9 \mathrm{ml}$ of water and dissolved by vortexing, and $0.9 \mathrm{ml}$ of the resulting ChromaVer3 solution was added to $0.1 \mathrm{ml}$ of standard or P. putida F1-containing sample and mixed. The reactions were incubated for 15 min at room temperature after which time the absorbance at $540 \mathrm{~nm}$ was read in a Beckman DU $530 \mathrm{UV} / \mathrm{Vis}$ Spectrophotometer (Beckman Coulter Inc., Fullerton, $\mathrm{CA}$ ) and the amount of $\mathrm{Cr}(\mathrm{VI})$ in each experimental sample was calculated from the standard curve. For each medium, a cell-free sample was monitored in parallel with the experimental cultures to control for abiotic $\mathrm{Cr}(\mathrm{VI})$ reduction.

\section{Sample preparation}

P. putida cultures harvested for shotgun proteomic analysis were lysed by sonication in $50 \mathrm{mM}$ Tris $/ 10 \mathrm{mM}$ EDTA (pH 7.6) as described previously [26]. Cellular debris was removed by centrifugation $(5,000 \times g$ for 10 $\mathrm{min}$ ), and the soluble proteome fraction was separated from the membrane fraction by ultracentrifugation $(100,000 \times g$ for $60 \mathrm{~min})$. The pellet (membrane fraction) was washed with $50 \mathrm{mM}$ Tris/10 mM EDTA (pH 7.6) and centrifuged at $100,000 \times g$ for $60 \mathrm{~min}$; this fraction was then resuspended in $50 \mathrm{mM}$ Tris/10 mM EDTA (pH 7.6) using brief sonication. Both proteome fractions (soluble and membrane associated) were quantified using the bicinchoninic acid (BCA) assay (Pierce, Rockford, IL), aliquoted, and maintained at $-80^{\circ} \mathrm{C}$ prior to protein digestion. Equal protein amounts $(1 \mathrm{mg})$ of each proteome fraction from each growth condition were diluted in $6 \mathrm{M}$ guanidine and $10 \mathrm{mM}$ dithiothreitol (DTT) followed by heat treatment $\left(60^{\circ} \mathrm{C}, 1 \mathrm{~h}\right)$. The proteome fractions were then digested with a 1:100 (wt/wt) amount of sequencing grade trypsin as described previously [26]. Following proteolytic digestion, samples were desalted using $\mathrm{C}_{18}$ SepPak solid phase extraction cartridges (Waters, Milford, $\mathrm{MA}$ ), concentrated to $\sim 10 \mu \mathrm{g} / \mu \mathrm{L}$ starting material, and solvent exchanged with $0.1 \%$ formic acid in HPLC grade water using a Savant SpeedVac (ThermoFisher Scientific, Waltham, MA). Samples were filtered, aliquoted, and stored at $-80^{\circ} \mathrm{C}$ until ready for two-dimensional (2-D) LCMS/MS analysis.

\section{D-LC-MS/MS measurements}

The digested proteome fractions (soluble and membrane) prepared from P. putida cells (cultivated in LB or M9L minimal medium, with or without $1 \mathrm{mM}$ chromate) were analyzed in duplicate via 2-D LC-MS/MS analysis using an Ultimate HPLC system (LC Packings, a division of Dionex, San Francisco, CA) coupled to a linear trapping quadrupole (LTQ) mass spectrometer (ThermoFisher Scientific, San Jose, CA). Details of the MS instrumentation are described elsewhere [26]. All samples were analyzed via a 24-h 12-step 2-D analysis consisting of increasing concentration $(0-500 \mathrm{mM})$ salt pulses of ammonium acetate followed by 2 -h reverse phase gradients from $100 \%$ aqueous solvent $\left[95 \% \mathrm{H}_{2} \mathrm{O} / 5 \%\right.$ acetonitrile (ACN) $/ 0.1 \%$ formic acid] to $50 \%$ organic solvent $\left(30 \% \mathrm{H}_{2} \mathrm{O} / 70 \% \mathrm{ACN} / 0.1 \%\right.$ formic acid). During the entire chromatographic process, the LTQ was operated in a data-dependent MS/MS mode as described in detail in Brown et al. [26]. 


\section{Proteome bioinformatics}

A protein database was created by combining the most recent version of the P.putida F1 genome database (available at the JGI website http://img.jgi.doe.gov/cgi-bin/ pub/main.cgi) containing a total of 5252 predicted proteins with 36 common contaminants (trypsin, keratin, etc.). For all database searches, the MS/MS spectra were searched using SEQUEST [49] with the following parameters: enzyme type, trypsin; parent mass tolerance, 3.0; fragment ion tolerance, 0.5 ; up to four missed cleavages allowed; fully tryptic peptides only as described previously [26]. The output data files were then filtered and sorted using the DTASelect algorithm [50] using the following parameters: fully tryptic peptides only with $\triangle \mathrm{CN}$ of at least 0.08 and cross-correlation scores (Xcorr) of at least $1.8(+1), 2.5(+2)$, and $3.5(+3)$. These threshold scores have been tested rigorously in our laboratory and provide a high confidence of identification with a maximum falsepositive rate of $1-2 \%$ [51]. Post-translational modifications and other fixed modifications were not included in the search parameters. The predicted proteome database, all resulting DTASelect files and extract files, as well as links to all identified spectra, are available at this website: http://compbio.ornl.gov/pseudomonas putida F1/ chromate response. The DTASelect results derived from LB and M9L media-grown cells were compared using the Contrast program [50] for each control and treatment condition. These results are located under the global contrast heading on the analysis page, as well as extract files with spectra, peptides and \% coverage for each protein identification.

\section{Statistical analysis}

The resultant proteome datasets were analyzed using the Poisson regression model as previously described [51]. The Poisson regression model is commonly used for count data, assuming that the data have a Poisson distribution and are relevant for differential proteome dataset analysis. In this study, the spectral counts for a protein in an experiment constituted the count data. As we evaluated medium and treatment effects separately, we only had a single independent variable in each model (medium or treatment). To make the spectral counts comparable across different experiments, the spectral counts for a protein were normalized to the total spectral counts for that given dataset. In Poisson regression, this is handled by adding the logarithm of total spectral counts as an independent variable with a fixed coefficient of 1 . The $p$ values generated by the model were further adjusted using the Benjamini and Hochberg correction to account for multiple comparisons [52]. An adjusted $p$-value of 0.01 (i.e., $1 \%$ False Discovery Rate, FDR) combined with a 2-fold change in expression were used to select for pro- teins that were differentially expressed between the two groups under comparison.

\section{Additional material}

\begin{abstract}
Additional file 1 Complete proteome data and dataset comparisons with statistical analysis. Complete dataset detailing the spectral counts for each treatment and its technical replicate. The extended table shows statistically analyzed comparisons between two treatments. Proteins that are highlighted show a two-fold change in expression and 1\% False Discovery Rate (FDR).

Additional file $\mathbf{2}$ Proteins detected in all technical replicates for cells grown in LB or M9L media. The table shows proteins detected in all technical replicates of cells grown in LB or M9L media [control and $\mathrm{Cr}(\mathrm{VI})$ shock] Additional file 3 Proteins unique to LB control compared to M9L control. Table lists proteins unique to unstressed LB grown cells compared to cells grown in M9L medium.

Additional file 4 Comparison of proteins expressed in unstressed cells grown in LB versus cells grown in M9L medium. Comparison of total proteins expressed in unstressed LB grown cells versus cells grown in M9L medium.

Additional file 5 Differential protein profile in control and $\mathrm{Cr}(\mathrm{VI})$ shocked M9L-grown cells. Datasheet shows differential protein profile of control and $\mathrm{Cr}(\mathrm{VI})$-shocked cells grown in M9L medium.

Additional file 6 Unique proteins induced in LB-grown cells and M9Lgrown cells in response to chromate. Table lists proteins uniquely expressed under $\mathrm{Cr}(\mathrm{VI})$ stress in LB and M9L grown cells.
\end{abstract}

\section{Authors' contributions}

DKT and GSW primarily conceived the study, helped prepare cell samples for proteomic analyses, supervised all physiological experiments, and performed the majority of the data interpretation and manuscript writing. KC performed the proteomic measurements, participated in the data interpretation, and helped to develop the proteomic datasets along with MS and NCV. SBT, ATM, and MAR carried out all of the physiological studies and chromate reduction assays for P. putida F1. BZ conducted the statistical analyses of the proteomic data and provided text for this portion of the manuscript. NCV and RLH coordinated and supervised the mass spectrometry studies. All authors read and approved the final manuscript.

\section{Acknowledgements}

This research was supported by the Office of Science (BER), U. S. Department of Energy, Environmental Remediation Sciences Program Grant No. DE-FG0207ER64391. Oak Ridge National Laboratory is managed by University of Tennessee-Battelle LLC for the Department of Energy under contract DOE-AC05OOOR22725.

\section{Author Details}

'Department of Biological Sciences, Purdue University, 915 W. State Street, West Lafayette, IN 47907, USA, ${ }^{2}$ Chemical Sciences Division, Oak Ridge National Laboratory, Oak Ridge, TN 37831, USA, ${ }^{3}$ Department of Biomedical Informatics, Vanderbilt University, Nashville, TN 37232, USA and 4Biosciences Division, Oak Ridge National Laboratory, Oak Ridge, TN 37831, USA

Received: 5 September 2009 Accepted: 19 May 2010 Published: 19 May 2010

\section{References}

1. Gibson DT, Koch JR, Kallio RE: Oxidative degradation of aromatic hydrocarbons by microorganisms I. Enzymatic formation of catechol from benzene. Biochem 1968, 7:2653-2661.

2. Timmis KN: Pseudomonas putida: a cosmopolitan opportunist par excellence. Environ Microbiol 2002, 4:779-781.

3. Cánovas D, Cases I, de Lorenzo V: Heavy metal tolerance and metal homeostasis in Pseudomonas putida as revealed by complete genome analysis. Environ Microbiol 2003, 5:1242-1256. 
4. von Canstein HF, Li Y, Felske A, Wagner-Döbler I: Long-term stability of mercury-reducing microbial biofilm communities analyzed by $16 \mathrm{~S}-23 \mathrm{~S}$ rDNA interspacer region polymorphism. Microb Ecol 2001, 42:624-634.

5. Chandler DP, Brockman FJ, Bailey TJ, Fredrickson JK: Phylogenetic diversity of Archaea and Bacteria in a deep subsurface paleosol. Microb Ecol 1998, 36:37-50.

6. Fields MW, Yan T, Rhee SK, Carroll SL, Jardine PM, Watson DB, Criddle CS, Zhou J: Impacts on microbial communities and cultivable isolates from groundwater contaminated with high levels of nitric acid-uranium waste. FEMS Microbiol Ecol 2005, 53:417-428.

7. James BR: The challenge of remediating chromium-contaminated soil. Environ Sci Technol 1996, 30:A248-A251.

8. Langard S: Chromium. In Metals in the Environment Edited by: Waldron HA. New York, Academy Press Inc; 1980:111-132.

9. Priester JH, Olson SG, Webb SM, Neu MP, Hersman LE, Holden PA: Enhanced exopolymer production and chromium stabilization in Pseudomonas putida unsaturated biofilms. Appl Environ Microbiol 2006, 72:1988-1996.

10. Ackerley DF, Gonzalez CF, Park CH, Blake R II, Keyhan M, Matin A Chromate-reducing properties of soluble flavoproteins from Pseudomonas putida and Escherichia coli. Appl Environ Microbiol 2004, 70:873-882

11. Park CH, Gonzalez CF, Ackerley DF, Keyhan M, Matin A: Molecular engineering of soluble bacterial proteins with chromate reductase activity. In Remediation and beneficial reuse of contaminated sediments Edited by: Hinche RE, et al. Columbus (Ohio), Batelle Press; 2002:103-111.

12. Ishibashi $Y$, Cervantes $C$, Silver S: Chromium reduction in Pseudomonas putida. Appl Environ Microbiol 1990, 56:2268-2270.

13. Knox AS, Brigmon RL, Kaplan DI, Paller MH: Interactions among phosphate amendments, microbes and uranium mobility in contaminated sediments. Sci Total Environ 2008, 395:63-71.

14. Wilson C, Brigmon RL, Knox AS, Seaman J, Smith G: Effects of microbial and phosphate amendments on the bioavailability of lead $(\mathrm{Pb})$ in shooting range soil. Bull Environ Contam Toxicol 2006, 76:392-399.

15. Nelson KE, Weinel C, Paulsen IT, Dodson RJ, Hilbert H, Martins dos Santos VAP, Fouts DE, Gill SR, Pop M, Holmes M, Brinkac L, Beanan M, DeBoy RT, Daugherty S, Kolonay J, Madupu R, Nelson W, White O, Peterson J, Khouri H, Hance I, Chris Lee P, Holtzapple E, Scanlan D, Tran K, Moazzez A, Utterback T, Rizzo M, Lee K, Kosack D, Moestl D, Wedler H, Lauber J, Stjepandic D, Hoheisel J, Straetz M, Heim S, Kiewitz C, Eisen JA, Timmis KN, Düsterhöft A, Tümmler B, Fraser CM: Complete genome sequence and comparative analysis of the metabolically versatile Pseudomonas putida KT2440. Environ Microbiol 2002, 4:799-808.

16. Eichhorn E, Ploeg JR van der, Kertesz MA, Leisinger T: Characterization of a-ketoglutarate-dependent taurine dioxygenase from Escherichia coli. J Biol Chem 1997, 272:23031-23036.

17. Ploeg JR van der, Weiss MA, Saller E, Nashimoto H, Saito N, Kertesz MA Leisinger T: Identification of sulfate starvation-regulated genes in Escherichia coli: a gene cluster involved in the utilization of taurine as a sulfur source. J Bacteriol 1996, 178:5438-5446.

18. Uria-Nickelsen MR, Leadbetter ER, Godchaux W III: Comparative aspects of utilization of sulfonate and other sulfur sources by Escherichia coli K12. Arch Microbiol 1994, 161:434-438.

19. Park CH, Keyhan M, Wielinga B, Fendorf S, Matin A: Purification to homogeneity and characterization of a novel Pseudomonas putida chromate reductase. Appl Environ Microbio/ 2000, 66:1788-1795.

20. Gonzalez CF, Ackerley DF, Lynch SV, Matin A: ChrR, a soluble quinone reductase of Pseudomonas putida that defends against $\mathrm{H}_{2} \mathrm{O}_{2}$. J Biol Chem 2005, 280:22590-22592.

21. Cervantes C, Ohtake H, Chu L, Misra TK, Silver S: Cloning, nucleotide sequence, and expression of the chromate resistance determinant of Pseudomonas aeruginosa plasmid pUM505. J Bacteriol 1990, 172:287-291.

22. Cervantes C, Campos-García J, Devars S, Gutiérrez-Corona F, Loza-Tavera H, Torres-Guzmán JC, Moreno-Sánchez R: Interactions of chromium with microorganisms and plants. FEMS Microbiol Rev 2001, 25:335-347.

23. Nies A, Nies DH, Silver S: Cloning and expression of plasmid genes encoding resistance to chromate and cobalt in Alcaligenes eutrophus. J Bacteriol 1989, 171:5065-5070.

24. Ohtake H, Cervantes C, Silver S: Decreased chromate uptake in Pseudomonas fluorescens carrying a chromate resistance plasmid. J Bacteriol 1987, 169:3853-3856
25. Ackerley DF, Barak Y, Lynch SV, Curtin J, Matin A: Effect of chromate stress on Escherichia coli K-12. J Bacteriol 2006, 188:3371-3381.

26. Brown SD, Thompson MR, VerBerkmoes NC, Chourey K, Shah M, Zhou J, Hettich RL, Thompson DK: Molecular dynamics of the Shewanella oneidensis response to chromate stress. Mol Cell Proteomics 2006, 5:1054-1071.

27. Thompson MR, VerBerkmoes NC, Chourey K, Shah M, Thompson DK, Hettich RL: Dosage-Dependent Proteome Response of Shewanella oneidensis MR-1 to Acute Chromate Challenge. J Proteome Res 2007, 6:1745-1757.

28. Henne KL, Turse JE, Nicora CD, Lipton MS, Tollaksen SL, Lindberg C, Babnigg G, Giometti CS, Nakatsu CH, Thompson DK, Konopka AE: Globa proteomic analysis of the chromate response in Arthrobacter sp. strain FB24. J Proteome Res 2009, 8:1704-1716.

29. Viti C, Decorosi F, Mini A, Tatti E, Giovannetti L: Involvement of the oscA gene in the sulphur starvation response and in $\mathrm{Cr}(\mathrm{VI})$ resistance in Pseudomonas corrugata 28. Microbiol 2009, 155:95-105.

30. Liu KJ, Shi X: In vivo reduction of chromium (VI) and its related free radical generation. Mol Cell Biochem 2001, 222:41-47

31. Hu P, Brodie EL, Suzuki Y, McAdams HH, Andersen GL: Whole-genome transcriptional analysis of heavy metal stresses in Caulobacter crescentus. J Bacteriol 2005, 187:8437-8449.

32. Polack B, Dacheux D, Delic-Attree I, Toussaint B, Vignais PM: The Pseudomonas aeruginosa fumC and soda genes belong to an ironresponsive operon. Biochem Biophys Res Commun 1996, 226:555-560.

33. Hassett DJ, Howell ML, Sokol PA, Vasil ML, Dean GE: Fumarase C activity is elevated in response to iron deprivation and in mucoid, alginateproducing Pseudomonas aeruginosa: cloning and characterization of fumC and purification of native fumC. J Bacteriol 1997, 179:1442-1451.

34. Marahiel MA, Stachelhaus T, Mootz HD: Modular peptide synthetases involved in nonribosomal peptide synthesis. Chem Rev 1997, 97:2651-2674

35. Quadri LEN, Keating TA, Patel HM, Walsh CT: Assembly of the Pseudomonas aeruginosa nonribosomal peptide siderophore pyochelin: in vitro reconstitution of aryl-4,2-bis-thiazoline synthetase activity from PchD, PchE, and PchF. Biochem 1999, 38:14941-14954.

36. Quadri LEN: Assembly of aryl-capped siderophores by modular peptide synthetases and polyketide synthases. Mol Microbiol 2000, 37:1-12.

37. Guterman SK: Colicin B: mode of action and inhibition by enterochelin. J Bacteriol 1973, 114:1217-1224.

38. Pugsley AP, Reeves P: Iron uptake in colicin B-resistant mutants of Escherichia coli K-12. J Bacteriol 1976, 126:1052-1062

39. Wang CC, Newton A: Iron transport in Escherichia coli: relationship between chromium sensitivity and high iron requirement of Escherichia coli. J Bacteriol 1976, 98:1135-1141.

40. Cortese MS, Paszczynski A, Lewis TA, Sebat JL, Borek V, Crawford RL: Metal chelating properties of pyridine-2,6-bis(thiocarboxylic acid) produced by Pseudomonas spp. and the biological activities of the formed complexes. Biometals 2002, 15:103-120.

41. Visca P, Colotti G, Serino L, Verzili D, Orsi N, Chiancone E: Metal regulation of siderophore synthesis in Pseudomonas aeruginosa and functional effects of siderophore-metal complexes. Appl Environ Microbiol 1992, 58:2886-2893

42. Zawadzka AM, Crawford RL, Paszczynski AJ: Pyridine-2,6bis(thiocarboxylic acid) produced by Pseudomonas stutzeri KC reduces and precipitates selenium and tellurium oxyanions. Appl Environ Microbiol 2006, 72:3119-29.

43. Zawadzka AM, Crawford RL, Paszczynski AJ: Pyridine-2,6bis(thiocarboxylic acid) produced by Pseudomonas stutzeri KC reduces chromium(VI) and precipitates mercury, cadmium, lead and arsenic. Biometals 2007, 20:145-58.

44. Hoch JA: Two-component and phosphorelay signal transduction. Curr Opin Microbiol 2000, 3:165-170.

45. Stock AM, Robinson VL, Goudreau PN: Two-component signal transduction. Annu Rev Biochem 2000, 69:183-215.

46. Kenny LJ: Structure/function relationships in OmpR and other wingedhelix transcription factors. Curr Opin Microbio/ 2002, 5:135-141.

47. Chourey K, Wei W, Wan XF, Thompson DK: Transcriptome analysis reveals response regulator $\mathrm{SO} 2426$-mediated gene expression in Shewanella oneidensis MR-1 under chromate challenge. BMC Genomics 2008, 9:395 
48. Schmieman EA, Younger DR, Rege MA, Petersen JN, Turick CE, Johnstone DL, Apel WA: Comparative kinetics of bacterial reduction of chromium. J Environ Eng ASCE 1998, 124:449-455.

49. Eng JK, McCormack AL, Yates JR III: An approach to correlate tandem mass spectral data of peptides with amino acid sequences in a protein database. J Am Soc Mass Spectrom 1994, 5:976-989.

50. Tabb DL, Hayes-McDonald W, Yates JR: DTASelect and contrast: tools for assembling and comparing protein identifications from shotgun proteomics. J Proteome Res 2002, 1:21-26.

51. Chourey K, Thompson MR, Shah M, Zhang B, VerBerkmoes NC, Thompson DK, Hettich RL: Comparative temporal proteomics of a response regulator (SO2426)-deficient strain and wild-type Shewanella oneidensis MR-1 during chromate transformation. J Proteome Res 2009, 8:59-71.

52. Benjamini $Y$, Hochberg $Y$ : Controlling the false discovery rate: a practical and powerful approach to multiple testing. J R Statist SOC B 1995, 57:289-300

doi: 10.1186/1471-2164-11-311

Cite this article as: Thompson et al., Proteomics reveals a core molecular response of Pseudomonas putida F1 to acute chromate challenge $B M C$ Genomics 2010, 11:311

Submit your next manuscript to BioMed Central and take full advantage of:

- Convenient online submission

- Thorough peer review

- No space constraints or color figure charges

- Immediate publication on acceptance

- Inclusion in PubMed, CAS, Scopus and Google Scholar

- Research which is freely available for redistribution

Submit your manuscript at www.biomedcentral.com/submit
C) Biomed Central 